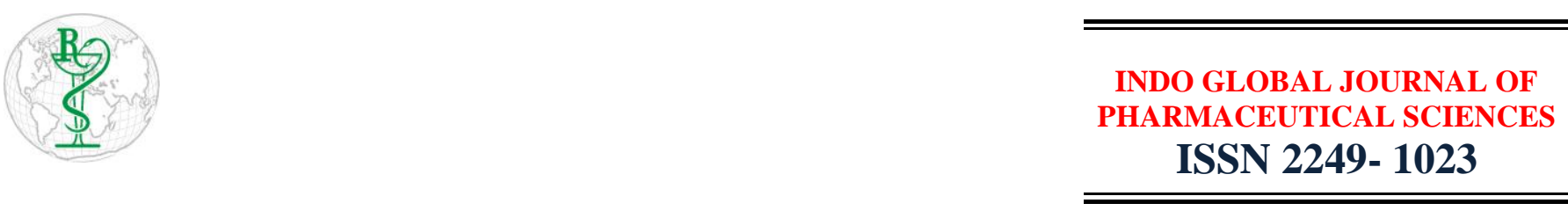

\title{
Exploring Natural Drugs for the Treatment of Diabetes Mellitus
}

Address for Correspondence: Navdeep Kaur; kaurnavdeep987@gmail.com

\begin{abstract}
Received:
01.03.2019

Accepted:

25.03.2019

Keywords

Diabetes

mellitus;

hypoglycemic

drugs,

Momordica

charantia,

Cinnamomum

zeylanicum.
\end{abstract}

\author{
Navdeep Kaur ${ }^{1}$, Pooja Sharma ${ }^{1,2}$, Dinesh Kumar ${ }^{1 *}$ \\ ${ }^{1}$ Sri Sai College of Pharmacy, Manawala, Amritsar-143115, Punjab, India \\ ${ }^{2}$ Department of Pharmaceutical Sciences and Drug Research, Punjabi University Patiala, Punjab, India
}

\begin{abstract}
Diabetes mellitus (DM) is a hereditary, chronic metabolic disease that results from an absolute or relative deficiency of insulin or impaired insulin action. It is predictable that 415 million people were suffering from diabetes mellitus. Type I diabetes is caused due to insulin insufficiency because of lack of functional beta cells and over 97,700 children were having type I whereas Type II diabetes is caused due to body's inability to respond to insulin and nearly 69.2 million people have type II. $46 \%$ of people with diabetes are undiagnosed. The ubiquity of DM is expected to reach upto $4.4 \%$ in the world by 2030 . However, advanced therapies are more effective than traditional drugs but having numerous side effects which are fatal for human health. Moreover, they are easy to use, lesser economic cost and better patient compliance. There are several natural drugs used in the treatment of diabetes such as Allium sativum, Eugenia jambolana, Momordica charantia, Cinnamomum zeylanicum, Phyllanthus amarus, Pterocarpus marsupium, Tinospora cordifolia, Trigonella foenum gracecum and Withania somnifera. M. charantia contains terpenoidal compound known as charatin which exhibits the hypoglycaemic effect. Cinnamaldehyde is a polyphenolic compound that is obtained from the plant Cinnamomum zeylanicum which is also responsible for the treatment of diabetes. (c) 2019 iGlobal Research and Publishing Foundation. All rights reserved.
\end{abstract}

Cite this article as: Kaur; N..; Sharma, P.; Kumar, D. Exploring Natural Drugs for the Treatment of Diabetes Mellitus. Indo Global J. Pharm. Sci., 2019; 9(2Suppl.): 135. DOI: http://doi.org/10.35652/IGJPS.2019.92S33.

Indo Global Journal of Pharmaceutical Sciences( ISSN 2249 1023; CODEN- IGJPAI; NLM ID: 101610675) indexed and abstracted in CrossRef (DOI Enabling), UGC CARE Journal List, EMBASE(Elsevier), National Library of Medicine (NLM) Catalog, ResearchGate, Publons, CAS (ACS), Index Copernicus, Google Scholar and many more. For further details, visit http://iglobaljournal.com

This is a special issue as an outcome of 'RAPSCON-2019' sponsored by APTI and organized by Sri Sai College of Pharmacy, Manawala, Amritsar, Punjab, India. Relaxation offered in journal format. 